\title{
Studies on Uygur Folk Story Translation by Zhao Shijie
}

\author{
Hongxia Wu \\ Southwest University for Nationalities, Southwest Minzu University, Chengdu, 610041, China
}

Keywords: Zhao Shijie; Uygur folktale; translation; Afanti

\begin{abstract}
Famous literary translator Zhao Shijie who has collected and translated many Uyghur folktales is well received among readers. The translated Uyghur folktales show up in various bookstores, make great contributions to the development of Uyghur folktales while providing a platform for people to understand the Uyghur folktales. This paper studies the translator Zhao Shijie and his translated Uyghur folktales, and highly appreciates his contribution to Uighur translation career while revealing his translation characteristics.
\end{abstract}

\section{Introduction}

Uyghur nationality as an important member of the Chinese ethnic peoples have abundant cultural resources. Uyghur folk literature is also an important constituent part of Chinese folk literature. Because of the underdevelopment of ancient Chinese characters, Uighurs have rich oral literature resources, such as myths, legends, stories, epics, proverbs, and folk songs from mouth to mouth. With social progress and development of characters, many Uyghur literatures are written and become matured. ${ }^{[2]}$ Among all, Uyghur folktales as the indispensable part of Uyghur literature attracted great attention in its development and dissemination which cannot separate with the written records of the characters apart from original oral recitation. To spread to more extensive communication area among larger population, it is even more inseparable with translation and even electronic media. Therefore, literary translators working one Uyghur folktale translation occupy an important position. The literary translator Zhao Shijie has translated a lot of Uyghur folktales, among which Afanti story collection has the greatest effect.

\section{Introduction to Zhao Shijie's translation}

Zhao Shijie very fond of folk literature accidentally heard the name of Avanti and developed great interest in 1952 during the land reform work in the Bash district of Aksu County. Three years later, he published his own Afanti joke story works translated by himself. In 1958, he published bilingual collection of Avanti stories. By now, he has published at least 16 translation works. Among them, The Story of Afanti, published by China Juvenile and Children's Books Publishing House in 1963, won the third prize in 1980 National Juvenile and Children's Literature Creation Awards, the revised edition of which listed as one of the 10 recommended books of the "1982 Red Scarf Reading Award" activity by China Youth Daily, was included in the "Series Books for Primary School Students" by the Beijing Municipal Education Bureau. It has been printed for 15 times with over 1 million copies until now, and translated into various foreign languages for publication; The Collected Joke Stories of Afanti won the first prize in the 2nd Northern China Excellent Folk Literature Award Activity in 1995. ${ }^{[1]}$ he is also be praised as the father of " Afanti "

At present, the Chinese edition of Uighur folk tales translated by Zhao Shijie with extensive dissemination in the network and bookstores are widely and well favored among readers, such as: "Selected Uyghur Folk Tales: Eat Tomorrow For Free", "Selected Uygur Folk Tales: Three Great", " Selected Uygur Folk Tales: Hunter Marries Wolf Girl", " Selected Uygur Folk Tales: Why is there a dragon on the moon", "Selected Uyghur Folk Tales: Play Suona in Midnight", " Selected Uygur Folk Tales: The Old Man Growing Gold", "Selected Uygur Folk Tales: Girl Raised by Mongolian gazelle", 
" Selected Uyghur Folk Tales: King Azadan and Bahetiar" and so on.

\section{Zhao Shijie's affection for Afanty}

\subsection{Discover Afanty}

Among Uyghur folk literature, a type of stories are about witty characters, such as the widely known stories of the witty characters Mullah Nasrdin and Nasrdin Avanti. Avanti is a honorific title with the meaning of "Mr." and "Teacher", as well as the title of knowledgeable people. The world figure Afanti appears in different Arab countries, Pakistan, Turkey, Iran, and Xinjiang of China. The Pakistanis also tell the story of Mullah Nasrdin who is identical to Avanti with different names due to different nationalities. ${ }^{[2]}$ In August 1952, Zhao Shijie was very excited after accidentally discovering the story of Avanti. Later, he learned from the Uighur people that Avanti is a representative of the witty character in the Uygur ethnic group with strong nationality and regionalism among the mass. ${ }^{[3]}$ Uyghur females or males can tell endless funny and life-savvy Avanti stories, so Zhao Shijie developed love with the Avanti stories, focused on listening to the stories of Avanti and took the initiative to ask the fellows during daily life exchanges with Uighurs. Then, he recorded the stories of Avanti into words, making the image of Avanti more and more bright.

\subsection{The description process of the Avanti story}

Since 1953, he began to collect and sort the story material of Afanti. He found that the wide spreading and well-known stories of Afanti were not published in written form, so he decided to translate them into Chinese for understanding by the whole country and people in all ethnic groups. In 1955, he translated and published about 20 stories of Afanti. In 1956, he sorted and compiled more than 100 stories of Afanti. In 1958, he took the first to launch the first Chinese edition the country. In 1963, collection of more than 100 Afanti stories were printed to 380,000 copies by China Juvenile and Children's Books Publishing House, and was well received by readers. In the mid-1980s, two of his "Story of Afanti " were translated into Spanish, French, and Bengali and published abroad. "Story of Afanti" was later adapted for the screen in the form of animation or an opera. Since from 1996, Xinjiang Publishing House contacted Mr. Zhao Shijie to publish Uyghur folk literature, stories of Afanti collected, collated and translated by him for years, such as "The Essentials of Afanti ", "The Complete Collection of Afanti Stories", "Story of Afanti (phonetic)". Later, he chose some Afanti stories together with Hubei Children's Publishing House, and then published Afanti comic strips with Afanti's characters of "witty", "wisdom", "smart" and "humor" as the theme in the art form of straightaway picture-story book.

In marketization era, Afanti also promoted a lot of diversified "Afanti" products, such as "Afanti" drama, music and film and television works, "Afanti" theme park; "Avati" puppets and toys, "Afanti" comics and so on. Among all, animation produced by the Shanghai Fine Arts Film Studio in the 1980s as the childhood memory for many people had great impact. The animation displaying a vivid image of Afanti reversely on the donkey with curved beard who fought the evil in an entertaining way is deeply loved by the audience. Zhao Shijie made the Afanti stories step out of Xinjiang and go to the whole country in the form of character. This animation "Story of Aventi " displaying the image of Afanti actively on the screen and in people's mind in a dynamic form turns t Zhao Shijie's Afanti stories dynamic and lifelike. People love Afanti's story because he is the embodiment of the brave and smart labor people against evil and the representative of thousands of laborers in addition to his humorous and interesting behaviors. In summary, people's love for the Afanti stories manifests their affirmation of the rich cultural and literary values contained in Afanti stories. 


\section{The characteristics of Uyghur folktale translation by Zhao Shijie}

\subsection{Rich variety}

In addition to the famous " Story of Afanti ", Zhao Shijie also translated "Selected Uyghur Folk Tales: Eat Tomorrow For Free", "Selected Uygur Folk Tales: Three Great", " Selected Uygur Folk Tales: Hunter Marries Wolf Girl", " Selected Uygur Folk Tales: Why is there a dragon on the moon", "Selected Uyghur Folk Tales: Play Suona in Midnight", " Selected Uygur Folk Tales: The Old Man Growing Gold", "Selected Uygur Folk Tales: Girl Raised by Mongolian gazelle", " Selected Uyghur Folk Tales: King Azadan and Bahetiar" and so on. The " Story of Afanti " is divided into five sections: chapter of Wisdom, chapter of King, chapter of Happiness, chapter of Humor, and chapter of Satir. Some contain hundreds of stories in rich varieties, involving animals, plants, tourist attractions, and people. Different Avanti stories vary in length, and some are accompanied by some beautiful illustrations. Among all selected Uygur folk tales translated by him, some are dozens of folk stories, some are Uighur folklore masterpieces. As a whole, Uygur folk tales translated by him have extensive contents, diverse style, and easy to understand.

\subsection{Strong interestingness}

"Interest" as an important concept in aesthetics and literary aesthetics is widely used in ancient Chinese art theories, containing unique ancients' aesthetic spirit and cultural concepts. "Interest" as the concept of literary aesthetics contains the meanings in two aspects: one refers to the artist's aesthetic interest, and the other refers to a special aesthetic taste of the art work. Both have close relationship. The basic meaning of "interest" in literary works can be reflected in art works in three aspects: the artistic works with implications are meaningful with vivid aesthetic images and aesthetic images in unique singularity. [4] " interest" can be divided into various types in terms of the content and the form. Under normal circumstances, " interest " is used together with characters such as Xing and Wei, which have rich meanings.

Some of Uyghur folk tales translated by Zhao Shijie are peaceful and elegant. Some have splendid and magical storylines. Some stories are witty and humorous. Some stories with implied meanings are easy to understand and express the mass's likes and dislikes, right and wrong values. Furthermore, Uyghur folk tales translated by him are interesting without dullness when reading, properly displaying the humor of the Uighurs. For example, in the face of Burke ${ }^{[1]}$ who ate his honey-dew melon, Afanti sarcastically said, "a freeloader must feel tasteless for the food. Its taste is in your pocket!" ${ }^{[2]}$ It shows the image of Burke who loves to gain extra advantages in a humorous way. Another example is that he describes with the word "grovel" in the story of "Melon and Watermelon" when melon famer Silimu is facing all watermelons in the ground. He compares melon and watermelon to living people. The word shows a good harvest in the orchard, and shows the joy of Silimu faced with the harvest.

\subsection{Prominent nationality and regionalism}

Zhao Shijie pays great attention to t Uyghur he original style in his translation. People can feel unique customs and culture of Uyghurs when reading his works. His works contain plenty of Uighur vocabularies, such as pilaf, naan, oil tower, and Xialafu(wine) in the Uyghur diet vocabulary; Zhangxue (teacher) in professional vocabulary, and Kazi (judge); Sapayi (percussion instrument), playing Bu'er (plucked stringed instrument); Dafu (tambourine); animal vocabulary Zenanfu(red-billed leiothrix), Hakai Kuai (Cuckoo bird), Patil Jock (Gecko); others such as Bi Xiukai (table); Railay (hollyhock); Lukema (miracle-working doctor); Sanmander(fruit); tuck (grape), Kuhong (melon, cantaloupe), Badanmu and so on. Readers can not only learn about these different knowledges, but can also understand them. The naan pit, the kaner well and the kantuman are daily life things among Xinjiang Uygur people closely related to Uighurs' life. He can better preserve the original appearance of Uyghur folk tales during translation, display Uygur people's daily life to 
readers, and make great contribution to the development of Uyghur folk tales.

\section{Conclusion}

Uighur literary translation developed through several stages. From the beginning of this century to the establishment of People's Republic of China on October 1st, 1949, it is the initiating period, or germination stage of Chinese translation of Uyghur folk literature. ${ }^{[7]}$ From the founding of the People's Republic to 1966, the Chinese translation of Uighur folk literature thrived during these seventeen years. During ten years after 1966, there were no change or development of the collection and translation of Uyghur folk literature. During the period before the 1990s, it was in the process of revival. Since the beginning of 1980s until now, Xinjiang translation literature has continued its prosperity and development, with more and more translation works. Literary translation is expressed through translator's personal thinking and language habit after entering into a new kind of cultural context and another language structure, thus establishing a new literature-- translated literature. ${ }^{[8]}$ Literary translation is a creative knowledge involving problems in different aspects. Xinjiang with superior geographical position is not only a multi-ethnic residential area, but also a key position of land transportation to connect Eurasia. Ethnic groups in this environment keep continuous interaction and communication in politics, economy, culture and life. In this process, as different people speak different languages, translation has naturally emerged and become a tool for communication between different nationalities.

Uyghur folk tales translated by Zhao Shijie are in diverse types and rich contents, with interestingness, which can reflect the characteristics of Uygur folk tales with strong nationality and regionalism. Uyghur folktales translated by him have made outstanding contributions to the protection and inheritance of Uyghur folktales while being widely and deeply received by readers.

\section{Acknowledgement}

This research was financially supported by the 2018 Southwest University for Nationalities doctoral candidate's innovation-type scientific research project "Uighur literature from western scholars' perspective in the early 20th century-take Uyghur folk literature by Swedish Gunnar Jarring as the example" (Project No. CX2018BS21) Phased achievement.

\section{References}

[1] Chinese translator -Zhao Shijie (534), Niu Kaixuan- "Network, http://blog.sina.com.cn/s/blog_584f805201017o1a.html.

[2] Tang Mengsheng, Kong Julan. Mullah Nasrdin and Afanti, Foreign Literature,1989:41.

[3] Ma Xinhe. Close relationship between Zhao Shijie and Avanti, partner monthly, 2002:4.

[4] Zheng Qunhui. The Theory of "Interest"—_ One of the Researches of Ancient Literary Theory, Journal of Jinan University (Philosophy and Social Sciences Edition). 2006:133.

[5] It is a Turkic transliteration, meaning "the chief" and "manager".

[6] Zhao Shijie. The Story of Afanti, Yunnan Art Publishing Press 2017:009.

[7] Yi Ming Abra. Chinese Translation and Characteristics of Uygur Folk Literature in the 20th Century. Language and Translation, 2000: 47.

[8] Edited by Chen Shiming, Ethnic-Chinese bilingual phenomenon in Xinjiang and relationship with social development, Nationalities Publishing House, 2010:262. 